\title{
Relationship between HIV Counseling and Testing (HCT) Awareness and HCT Uptake among Young People in Nigeria: Implications for Social Change
}

\author{
Adaeze Oguegbu' ${ }^{1}$, Frazier Beatty ${ }^{2}$ \\ ${ }^{1}$ Department of Public and Community Health, Liberty University, Lynchburg, VA, USA \\ ${ }^{2}$ Walden University, Minneapolis, MN, USA \\ Email: aoguegbu@kaplan.edu
}

How to cite this paper: Oguegbu, A. and Beatty, F. (2016) Relationship between HIV Counseling and Testing (HCT) Awareness and HCT Uptake among Young People in Nigeria: Implications for Social Change. Worla Journal of AIDS, 6, 123-136.

http://dx.doi.org/10.4236/wja.2016.64016

Received: August 8, 2016

Accepted: November 1, 2016

Published: November 4, 2016

Copyright $\odot 2016$ by authors and Scientific Research Publishing Inc. This work is licensed under the Creative Commons Attribution International License (CC BY 4.0).

http://creativecommons.org/licenses/by/4.0/ c) (i) Open Access

\section{Abstract}

This study examined the relationship between HIV counselling and testing (HCT) awareness and HCT uptake among young people in Nigeria and their implications for social change. The study is a quantitative research guided by one research question and one hypothesis. The target population comprised young people in Nigeria ages 15 to 24 years because the focus of this study was to identify the factors affecting HCT uptake among young people in this age cohort. The representative sample was obtained from the updated master sample frame of rural and urban zones developed by the National Population Commission in Nigeria. This master sample frame was a national survey that comprised all 36 states in Nigeria. Probability sampling technique was used to obtain a sample of 10,091 respondents (ages 15 to 24 years) for the study. The multistage cluster sampling was used to select suitable young people with known probability. Data were collected throughout Nigeria between September and December 2012 from 32,543 households (rural = 22,192; urban $=10,351$ ) using structured and semi-structured questionnaires. The individual questionnaires asked about household characteristics, background characteristics of the respondents. Data were analyzed by inputting them into SPSS v21.0 for analysis and then coded them for each participant. The data were summed using descriptive statistics. Frequencies and percentages; measures of central tendencies were used to answer the research question while nonparametric tests such as chi-square were used to analyze non-normally distributed data at 0.5 level of significance. The results of the chi-square test of association between HCT awareness and HCT uptake showed that there was a statistically significant relationship between HCT awareness and HCT uptake among young people ages 15 to 24 years in Nigeria, $\mathrm{X}^{2}(1, n=8916)=306.66, p<0.001$. In other words, knowledge of the availability of HCT services may have influenced the possibility that the participants would use them. Among others, it was recommended 
that government should examine the efficacy of HCT treatments in Nigeria, along with conducting a demographic analysis of the at-risk population.

\section{Keywords}

HIV Counselling, Testing, Awareness, HCT Uptake, Young People, Social Change

\section{Introduction}

Previous researchers have reported that HIV infection affects all members of society, particularly young people ages 15 to 24 years [1] [2]. Two factors influencing the spread of HIV are sexual experimentation and the belief in one's invincibility [3]. This claims that adolescence constitutes heightened sexual drive among young people, thus contributing to their vulnerability to the risks of acquiring HIV, was supported by the World Health Organization [4]. Among all age groups, girl ages 15 to 19 years have the highest prevalence of gonorrhea and young people are the most vulnerable to acquiring HIV infection [5].

Previous researchers have reported that the sexual risk behavior of young people has become one of the most pressing public concerns [6] [7] [8]. It is traditional for every society to restrict young people from receiving sexual education in the mistaken belief that ignorance about sex will lead to chastity. With regard to the factors affecting HCT uptake among young people in Nigeria, a considerable number of young people receive insufficient information about HIV infection [9]. According to the National Agency for the Control of AIDS [10], 86\% of young people in Nigeria have heard about HIV. Radio and other mass media have been the primary sources of information about HIV among Nigerian youth [1]. However, despite enough information about HIV, there is limited information about HCT centers across the country [11]. Knowledge about HIV, cultural beliefs, and traditions predict attitudes toward HCT [1]. The results showed that knowledge of HIV was the most resilient predictor of factors associated with HCT uptake among young people in Nigeria $(\beta=0.547 ; t=3.458, p<0.05)$, closely followed by cultural beliefs $(\beta=0.324 ; t=2.740, p<0.05)$ and sexual behavior $(\beta=0.041 ; t=0.543$, $p>0.05)[1]$.

An important factor that significantly predicts the uptake of HCT is self-perceived risk of contracting HIV [11]. This perception has fascinated public health researchers because of the significance of risk perception to health beliefs and social cognitive behavioral models of health behavior [12] [13]. A cross-sectional study of 600 first-year university students from south India, South Africa, and the United States was conducted and they discovered that stigmatization and discrimination significantly affected HCT uptake among the young people in the study [14]. In Nigeria, peer pressure and the associated sense of belonging affect young people's decisions to use HCT services [15] [16].

Researchers have found an increase in HCT uptake in direct relation to the proximity 
of testing centers and the provision of services at a reduced or free cost; these relationships are significant at the .05 $\alpha$ level [17] [18] [19]. An increase in the number of HCT centers and better transportation to these centers could improve the uptake rates of HCT [10] [20] [21]. Based upon the review of the literature, several cognitive factors emerged as being associated with HCT uptake among young people. The researcher examined the various cognitive factors affecting HCT uptake among young people in Nigeria. The researcher also used the literature to identify the Independent Variables (IVs) of HCT awareness, knowledge of HIV prevention, and knowledge of HIV transmission and their relationship with HCT uptake among young people in Nigeria.

HCT has been used to identify new HIV-positive young people promptly and direct them to treatment, management, and support programs [22]. The results of the study by Mall et al. showed that the percentage of respondents who had undergone HCT were more likely to have a greater HIV knowledge score $(p=0.02)$. HCT centers provide a support system for young people in Nigeria, especially those living with HIV, by offering counseling services, testing, and reinforcement of healthy behaviors [23]. HCT centers can collect sociobehavioral data on individuals testing for HIV nationwide that could be used to ascertain the predisposing factors related to individuals who test positive within a geopolitical area of interest [18] [24] [25] [26]. These data constitute a rich resource for planning evidence-based interventions that can address the high prevalence rates of HIV within that geopolitical area [27]. HCT gives individuals access to emotional support, improves their skills to deal with HIV-related anxiety, and intensifies their motivation to engage in safe sexual behaviors [11] [28] [29].

A study examined the early determination of HIV status by routine HCT in Nigeria. The overall HIV prevalence was $6.4 \%$; $6.8 \%$ outpatients and $4.3 \%$ self-presenting HCT patients were HIV positive. The researchers identified a significant need for an expanded and more purpose-driven public education campaign showcasing the benefits of HCT; this type of campaign should be a priority for all HIV control organizations in Nigeria. HIV was significantly associated with gender among the respondents $(p<$ 0.001) [30]. The usefulness of HCT in the prevention of mother-to-child transmission of HIV is that early detection of the virus during pregnancy can help the mothers to make more informed decisions to prevent vertical HIV transmission [31] [32]. The community benefits from HCT because awareness of HIV status can lead to enhanced community mobilization against the epidemic and decrease HIV-related stigma and isolation [33].

Another study explored the acceptance and HCT uptake by youth corps members in Osun State, Nigeria. The National Youth Service Corps is an organization established by the Nigerian government to involve all graduates in the development of the country [34]. Oladunni and Osezua surveyed 300 youth corps randomly selected from three local government areas and discovered that $68 \%$ of the respondents were single, with a substantial number living with the opposite sex. A total of $9.4 \%$ of respondents had low knowledge and visited HCT centers; 90.6\% had low knowledge and had not visited HCT centers or been tested for HIV. The researchers concluded that the participants with lower knowledge of HCT were less likely to visit HCT centers for testing ( $p<$ 
$0.05)$.

Cohabiting with the opposite sex predisposes youth to engage in unprotected sexual intercourse [35] [36]. Young people do not consider themselves susceptible to HIV infection, a belief that clarifies their negative attitude to using HCT services [15] [34]. Again, another study invesitgated the knowledge, risk perceptions, and behaviors toward HIV among university students in Lagos and discovered that perceived risk of HIV had a substantial effect on decisions about prevention practices and HCT [37]. Another study found a significant relationship between awareness of HCT and knowledge of HIV status $\left(X^{2}=11.92, p=0.00056\right)$ [28].

A study examined the knowledge, attitudes, practices, and uptake of HCT among girl ages 15 to 19 years in designated secondary schools in Malawi. They discovered that although virtually every student knew about HCT, HCT uptake was low: Only one third of the students had been tested for HIV, and HCT uptake increased with age [38]. Young people have a high knowledge of their serostatus predominantly as the result of provider-initiated HIV testing [28] [39]. In addition, 69\% of the young girls who did not know their serostatus felt that they were not sexually active or not at risk [38]. A comparable negative attitude was observed among university students in Kano and Benin toward the use of ART [30] [40]. Several researchers have noted that young people do not use HCT services because they fear societal discrimination and misunderstand the etiology of HIV, resulting in a complete distortion or nondisclosure of their HIV status [41] [42] [43]. Furthermore, it was reported that the low uptake of HCT among young people was significantly associated with the lack of awareness of HCT centers [44]. All studies mentioned in the literature review supported the need to address the research gaps that exist in HCT uptake among young people in Nigeria.

According to the Integrated Biological and Behavioral Surveillance Survey [45], there are three major HIV transmission routes in Nigeria: heterosexual sex, blood transfusions, and mother-to-child transmission. Approximately $80 \%$ of HIV infections in Nigeria have been the result of heterosexual sex, which affects young women in particular [46]. In 2011, an estimated 1.7 million women were living with HIV, and the prevalence was 3\% among young women ages 15 to 24 years [46] [47]. Causative factors have included a lack of sexual health and HIV awareness, inadequate and inappropriate condom use, and an increase in Sexually Transmitted Diseases [48]. Gender inequality is the major reason for the high HIV rates among young women in Nigeria [17]. Nigerian society is predominantly patriarchal, and the average young woman is susceptible to prostitution, compulsory marriage, street hawking, and trafficking [49].

One of the major factors leading to the spread of the HIV epidemic in Nigeria has been the sexual risk-taking behaviors of young people ages 15 to 24 years [50]. Obidoa et al. reported that national and local surveys have shown that the rate of unprotected sex among young people ages 15 to 24 years remains high, despite the prominent threat of HIV in Nigeria. They added that sexual risk-taking behaviors involve first intercourse at early age, inconsistent condom use, transactional sex, and sex with multiple partners [50]. A survey conducted by the Federal Ministry of Health (FMOH) indicated 
that although $22 \%$ and $17.4 \%$ of never-married young women and men ages 15 to 19 years, respectively, had engaged in sex within the last 12 months, only $23 \%$ of the women and $32.8 \%$ of the men had used condoms during their last sexual encounters and that $4.9 \%$ of the men within the same age range reported having two or more sexual partners [45].

Female sex workers are the most vulnerable group in Nigeria: Those who work at brothels have an HIV prevalence rate of $27.4 \%$; those who do not have a rate of $21.1 \%$. Men having sex with men (MSM) and injecting drug users have prevalence rates of $17.2 \%$ and $4.2 \%$, respectively; transport workers have a HIV prevalence rate of $2.4 \%$ [45]. Approximately 85,000 infants in Nigeria are at risk for mother-to-child HIV transmission every year [51] [52]. Blood transfusions are the second largest route of HIV transmission in Nigeria because most Nigerian hospitals do not have the technology to screen blood efficiently, thus increasing the risk of using contaminated blood [53]. To help to address the issue of HIV transmission via blood transfusion, the FMOH approved a bill that requiring every hospital in Nigeria to use only blood from the National Blood Transfusion Service, which has ultramodern blood-screening technology. In view of the above backdrop, this study examined the relationship between the cognitive factor of HCT awareness and HCT uptake among young people in Nigeria [48].

\section{The Limitations of Study}

The limitation of this study was the probability of a social interest bias from self-reported data, especially for a disease like HIV/AIDS. Nevertheless, as a result of the intricate nature of HIV in Nigeria, a survey was the most effective tool to evaluate this variable [32] [43] [48]. The National HIV/AIDS Reproductive Health Survey (NARHS) Plus data collectors used various methods to create a friendly atmosphere to ensure that the respondents were relaxed while completing the survey [48]. One way was to provide the survey respondents with a confidentiality agreement guaranteeing complete anonymity, a strategy that addressed criterion validity. Professional and experienced data collectors were used to collect data for the NARHS Plus.

\section{Purpose of the Study}

The main purpose of this study was to examine the relationship between the cognitive factor of HCT awareness and HCT uptake among young people in Nigeria.

\section{Research Question}

What is the relationship between the cognitive factor of HCT awareness and HCT uptake among young people in Nigeria?

\section{Hypothesis}

$H_{02}$ : There is no significant relationship between HCT awareness and HCT uptake among young people in Nigeria. 
$H_{\mathrm{a} 2}$ : There is a significant relationship between HCT awareness and HCT uptake among young people in Nigeria.

\section{Research Methodology}

This study is a quantitative research. Quantitative research is deductive and confirmatory. The design used in the study was a non-experimental, cross-sectional research design [54]. This design was adopted because the data were collected only once in 2013. Again, the use of secondary data made a cross-sectional design the most appropriate for this study.

The target population comprised young people in Nigeria ages 15 to 24 years because the focus of this study was to identify the factors affecting HCT uptake among young people in this age cohort. This age group was considered because according to the NARHS Plus [48], individuals aged 15 to 24 years are considered young adults. The representative sample was obtained from the updated master sample frame of rural and urban zones developed by the National Population Commission in Nigeria. This master sample frame was a national survey that comprises all 36 states in Nigeria [48]. Probability sampling technique was used to obtain a sample of 10091 respondents (ages 15 to 24 years) for the study. The multistage cluster sampling was used to select suitable young people with known probability. Stage 1 involved the selection of rural and urban zones. Stage 2 involved the selection of enumeration areas within the selected rural and urban zones. The listing and selection of households were conducted in Stage 3, and Stage 4 involved the selection of young respondents to complete the survey and participate in HIV testing. An already validated and reliable instrument titled 'The NARHS Plus Sexual Risk Behavior Scale' was adopted and used to measure sexual risk behaviors (i.e., sex with multiple partners, engagement in intergenerational sex, and engagement in transactional sex). The NARHS Plus was nationally represented to gather information about HIV and AIDS, RH knowledge, and behavior-related issues. Data were collected using three structured and semi-structured questionnaires. Three questionnaires comprised the NARHS Plus [48]: The Household Questionnaire [55]; the Women's Questionnaire [55]; and the Men's Questionnaire [55]. The questionnaires and all survey procedures were translated and piloted prior to implementation in the NARHS Plus [48]. The individual questionnaires asked about household characteristics, background characteristics of the respondents, sexual behaviors, knowledge and awareness of HIV and AIDS, personal risk perceptions of contracting HIV, condom accessibility and usage, stigma and discrimination, malaria prevention, exposure to health communication, reproductive rights and violence against women, maternal mortality, and vesicovaginal fistulae [48].

Data were collected throughout Nigeria between September and December 2012 from 32,543 households (rural $=22,192$; urban $=10,351$ ) using structured and semistructured questionnaires. Out of the households, a total of 31,235 individual respondents were interviewed using the NARHS Plus [48]. Among the individual respondents, 15,596 were men, and 15,639 were women, resulting in a response rate of $88 \%$. The data 
set was released in December 2013 by the FMOH, but it is not yet available to the public. Secondary data were collected from 31,235 respondents who were interviewed using the NARHS Plus to obtain the required sample size, which comprised young people in Nigeria ages 15 to 24 years, data were filtered to include only individuals in that age range (10,091 individuals).

Data were analyzed by inputting them into SPSS v21.0 for analysis and then coded them for each participant [56]. The data were summed using descriptive statistics. Frequencies and percentages; measures of central tendencies such as the mean, standard deviation, and range were used to answer the research question. Nonparametric test such as chi-square was used to analyze non-normally distributed data. The HCT uptake was measured as a categorical variable to indicate engagement with HCT among young people ages 15 to 24 years in Nigeria. Engagement with HCT was denoted as yes (1), and non-engagement with HCT was denoted as no (0).

\section{Results}

The research question investigated the relationship between the cognitive factor of HCT awareness and HCT uptake among young people in Nigeria. The hypothesis tested whether there significant relationship between HCT awareness and HCT uptake among young people in Nigeria.

Table 1 and Table 2 present the results of the chi-square test, with Table 1 presenting the cross-tabulation table for HCT awareness and HCT uptake and Table 2 presenting the chi-square test statistics. As observed in Table 1, there were 4 observations that had missing responses on HCT awareness, and as such, these observations were

Table 1. Cross-tab test for HCT awareness and HCT uptake.

\begin{tabular}{|c|c|c|c|c|c|}
\hline & & & \multicolumn{2}{|c|}{ Knowledge of where to obtain HCT } & Total \\
\hline \multirow{3}{*}{ HCT uptake } & \multirow{2}{*}{ No } & Count & 2837 & 4242 & 7079 \\
\hline & & $\%$ within knowledge of where to obtain HCT & $89.5 \%$ & $73.8 \%$ & $79.4 \%$ \\
\hline & Yes & Count & 333 & 1504 & 1837 \\
\hline \multirow{2}{*}{\multicolumn{2}{|c|}{ Total }} & Count & 3170 & 5746 & 8916 \\
\hline & & $\%$ within knowledge of where to obtain HCT & $100.0 \%$ & $100.0 \%$ & $100.0 \%$ \\
\hline
\end{tabular}

Table 2. Chi-square test for HCT awareness and HCT uptake.

\begin{tabular}{cccc}
\hline & Value & $d f$ & Asymp. sig. (2-sided) \\
\hline Pearson chi-square & 306.656 & 1 & 0.000 \\
Continuity correction & 305.699 & 1 & 1 \\
Likelihood ratio & 333.392 & & 0.000 \\
No. of valid cases & 8916 & & 0.000 \\
\hline
\end{tabular}


excluded from the chi-square test. The participants who had knowledge of where to obtain HCT were more likely to have HCT uptake relative to participants who had no knowledge of where to obtain HCT. The results of the chi-square test of association between HCT awareness and HCT uptake showed that there is a statistically significant relationship between HCT awareness and HCT uptake among young people ages 15 to 24 years in Nigeria, $\mathrm{X}^{2}(1, n=8916)=306.66, p<0.001$. The null hypothesis was rejected in favor of alternate hypothesis: There is a significant relationship between HCT awareness and the uptake of HCT among young people in Nigeria.

Results of the chi-square test for the hypothesis indicated that the cognitive factor of knowledge of where to obtain HCT was significantly associated with HCT uptake.

Tables 3-5 present the results of the binomial logistic regression test for knowledge of HIV prevention and HCT uptake. As illustrated in Table 3, both pseudo $R^{2}$ measures were very low, indicating that the model with knowledge of HIV prevention as the sole predictor variable was not a good fit for the data. Table 5 shows that the variable of knowledge of HIV prevention was a statistically significant predictor of the odds that the participants had HCT uptake $(\beta=0.13, p<0.001)$.

\section{Discussion}

The HCT uptake occurs when individuals actually undergo HIV counseling and testing [34]. HCT uptake was measured as a categorical variable to indicate engagement with HCT among young people ages 15 to 24 years in Nigeria. Engagement with HCT was denoted as yes (1), and non-engagement with HCT was denoted as no (0). Results of the multivariate binomial logistic regression, testing for all IVs as predictors of HCT

Table 3. Knowledge of HIV prevention test model summary table.

\begin{tabular}{cccc}
\hline Step & $-2 \log$ likelihood & Cox \& Snell $R^{2}$ & Nagelkerke $R^{2}$ \\
\hline 1 & 8943.590 & 0.014 & 0.022 \\
\hline
\end{tabular}

Table 4. Knowledge of HIV prevention classification table.

\begin{tabular}{|c|c|c|c|c|c|}
\hline & \multirow{3}{*}{ Observed } & & \multicolumn{3}{|c|}{ Predicted } \\
\hline & & & \multicolumn{2}{|c|}{ HCT uptake } & \multirow{2}{*}{$\%$ correct } \\
\hline & & & No & Yes & \\
\hline \multirow{3}{*}{ Step 1} & HCT untake & No & 7076 & 0 & 100.0 \\
\hline & 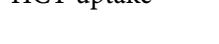 & Yes & 1837 & 0 & 0.0 \\
\hline & Overall \% & & & & 79.4 \\
\hline
\end{tabular}

Table 5. Knowledge of HIV prevention variables in equation table.

\begin{tabular}{cccccccc}
\hline & B & $S E$ & Wald & Df & Sig. & Exp (B) \\
\hline \multirow{2}{*}{ Step 1a } & HIVPrevKnowledge & 0.130 & 0.012 & 114.659 & 1 & 0.000 & 1.138 \\
& Constant & -2.131 & 0.080 & 707.226 & 1 & 0.000 & 0.119 \\
\hline
\end{tabular}


uptake, indicated that the factors were statistically significant predictors of the likelihood of having HCT uptake.

The study found that cognitive awareness of HCT was positively associated with HCT uptake. In other words, knowledge of the availability of HCT services may have influenced the possibility that the participants would use them. This result was in concurrence with the results of research by [34] [37] and [36], all of whom noted that the more often students and young people in general were made aware of the existence of HCT facilities, the more often they would take advantage of them.

Another element of cognitive awareness addressed in the study was knowledge of HIV transmission and knowledge of HIV prevention. The results showed that such knowledge was positively associated with HCT uptake. Participants who were aware of the factors in HIV transmission and what could be done to prevent it were more likely to take advantage of HCT facilities. High levels of knowledge of HIV transmission and HIV prevention but low levels of HCT uptake among the participants in their study. They identified specific cultural and societal factors that negated the influence of education in this regard and hence concluded that education alone is not enough to increase HCT uptake [38].

The tested hypothesis that greater awareness of where to obtain HCT was positively associated with HCT uptake also was reinforced by the Social Cognitive Theory (SCT) [57]. The more often knowledge of an HCT facility is disseminated among the public, the more frequently the public will take advantage of it. The SCT states that the acquisition of such knowledge comes through social contacts. People, especially those living in isolated or rural areas are simply unaware that HCT and other health care resources exist or are accessible [36].

Knowledge of the ways in which HIV is transmitted and how to prevent it is not common; rather, it must be obtained from others. In Nigeria, given the high incidence and death rates of HIV, it is very likely that many young people know others who have experienced the disease [40]. It also is likely that young people know others who have sought treatment for HIV [22]. These situations can be the motivation and the means to find out about HCT treatment, especially if and when young people contract the virus or want to know about preventive measures.

The problem addressed was the awareness and utilization of HCT services among young people in Nigeria because of factors related to gender, level of education, HCT awareness, knowledge of HIV prevention, knowledge of HIV transmission, geopolitical zone, place of residence, and SES. Lack of education can affect HCT uptake among young people in Nigeria [58]. Young people in Nigeria should be better educated about HCT uptake and HIV awareness, transmission and prevention. Since it is found that knowledge and awareness are significant factors that affect HCT uptake among young people in Nigeria, it is therefore recommended that government should examine the efficacy of HCT treatments in Nigeria, along with conducting a demographic analysis of the at-risk population. It is also recommended stringent measures be taken against stigmatization since it affects treatment decisions individuals who have contracted 
HIV/AIDS.

\section{Implications for Social Change}

On an individual level, the findings of this study could help to improve the health of Nigerians, especially young people and those who are at risk for HIV. One positive behavioral change for young people in Nigeria resulting from this study might be an increase in their use of HCT services. Young people could become more knowledgeable about HCT. Since health risk behaviors, like all behaviors, are at least in part learned from other in one's social contact circles [57], the education of peers could provide a reinforcing effect. Individuals who are aware of HCT could inform their peers of the importance of HCT uptake.

The community at large could benefit as well. The findings could help authorities in Nigeria to allocate scarce medical resources more efficaciously by identifying population cohorts with lower rates of HCT uptake. HCT is not only about treatment but also about education and prevention, so increasing HCT uptake could decrease mortality rates among individuals with HIV and also protect others from contracting it [58]. Existing programs could be focused on those areas and populations where the risk is highest. In addition, education programs could be implemented where they are most needed. At the national level, the results could be used to increase efforts to make HCT services more accessible by removing the barriers that can hinder the uptake of HCT among young people in Nigeria. The ultimate goal of this study is to effect positive and sustainable behavioral changes. For programs and interventions, each finding points toward a particular policy focus. For example, demographics information affecting HCT uptake suggests that the demographics of given areas should dictate where HCT facilities are located. Awareness of the existence and availability of HCT centers increases HCT uptake rates, hence substantial efforts should be made to increase public awareness of HCT facilities [31]. Knowledge of HIV transmission and knowledge of its prevention also can increase HCT uptake rates [9]. Serious and broad efforts should be made to educate the public on HIV transmission and prevention [11] [19] [29] [24]. Further, the academic community could benefit from the proliferation of HCT knowledge and awareness in Nigeria, which could lead to more strategic future studies and research.

\section{Funding}

No funding was received for this study.

\section{Conflict of Interest}

I declare that I have no conflict of interest.

\section{Ethical Approval}

This article does not contain any studies with human participants performed by any of 
the authors

\section{References}

[1] Adekeye, O.A. (2009) HIV Voluntary Counselling and Testing for Young People: The Antidote for a Healthy and Positive Living in Nigeria. Counsellor, 26, 13-26.

[2] Simbayi, L., Shisana, O., Chauveau, J. and Ramlagan, S. (2003) Determinants of the Use of Voluntary Counselling and Testing Services among the Sexually Active Adult Population of South Africa. Antivirus Therapy, 8, 161.

[3] Adekeye, O.A. (2005) Adolescents and the HIV Pandemic. Journal of the Postgraduate Students Association, University of Ilorin, 3, 23-28.

[4] World Health Organization (2014) HIV Testing Services. http://www.who.int/hiv/topics/vct/en/

[5] Adekeye, O.A., Ebiai, A. and Adeusi, S.O. (2011) Psycho-Cultural Variables Predicting Attitude of Students' towards HIV Counselling and Testing in Selected tertiary Institutions in Lagos State, Nigeria. Journal of Research in National Development, 9, 431-440.

[6] Papalia, D.E., Olds, S.W. and Feldman, R.D. (2001) Human Development. 8th Edition, McGraw Hill, Boston.

[7] Rwenge, M. (2000) Sexual Risk Behaviours among Young People in Bamenda, Cameroon. International Family Planning Perspectives, 26, 118-123. http://dx.doi.org/10.2307/2648300

[8] Toroitich-Ruto, C. (2000) The Effect of HIV/AIDS on Sexual Behaviour of Young People in Kenya. http://archive.iussp.org/Brazil2001/s00/S04 P07 Toroitich.pdf

[9] Akhigbe, R.E. and Bamidele, J.O. (2013) Prevalence and Pattern of Utilization of Voluntary Counseling and Testing Services and HIV Infection in Ogbomoso, Southwestern Nigeria. Journal of Natural Science, Biology and Medicine, 4, 163-166.

[10] National Agency for the Control of AIDS (2012) Global AIDS Response: Country Progress Report Nigeria. http://www.academia.edu/9469489/NARHS Plus 2012 Final 18112013

[11] Amu, E.O., Olatona, F.A. and Onayade, A.A. (2014) Factors Influencing HIV Counselling and Testing Uptake among Corps Members in Osun State, Nigeria. IOSR Journal of Dental and Medical Sciences, 13, 14-19. http://dx.doi.org/10.9790/0853-13141419

[12] Prochaska, J.O. and DiClemente, C.C. (1986) Toward a Comprehensive Model of Change. Springer, New York, 3-27. http://dx.doi.org/10.1007/978-1-4613-2191-0_1

[13] Ward, E.G., Disch, W.B., Levy, J.A. and Schensul, J.J. (2004) Perception of HIV/AIDS Risk among Urban, Low-Income Senior-Housing Residents. AIDS Education and Prevention, 16, 571-588. http://dx.doi.org/10.1521/aeap.16.6.571.53795

[14] Peltzer, K., Nzewi, E. and Mohan, K. (2004) Attitudes towards HIV-Antibody Testing and People with AIDS among University Students in India, South Africa and United States. Indian Journal of Medical Sciences, 58, 95-108.

[15] Daniyam, A.C., Agaba, A.P. and Agaba, I. (2010) Acceptability of Voluntary Counseling and Testing among Medical Students in Jos, Nigeria. Journal of Infectious Diseases in Developing Countries, 4, 357-361.

[16] Yahaya, L.A, Jimoh, A. and Balogun, R. (2010) Factors Hindering Acceptance of HIV/AIDS Voluntary Counselling and Testing (VCT) among Youths in Kwara State, Nigeria. Journal of AIDS and HIV Research, 2, 138-143.

[17] Iliyasu, Z., Kabir, M., Galadanci, H., Abubakar, I. and Aliyu, M. (2005) Awareness and Attitude of Antenatal Clients towards HIV Voluntary Counselling and Testing in Aminu 
Kano Teaching Hospital, Kano, Nigeria. Nigeria Journal of Medicine, J14, 27-32.

[18] Kalichman, S. and Simbayi, L. (2003) HIV Testing Attitudes, AIDS Stigma, and Voluntary HIV Counselling and Testing in a Black township in Cape Town, South Africa. Sexually Transmitted Infections, 79, 442-447. http://dx.doi.org/10.1136/sti.79.6.442

[19] Mall, S., Middelkoop, K., Mark, D., Wood, R. and Bekker, L. (2013) Changing Patterns in HIV/AIDS Stigma and Uptake of Voluntary Counselling and Testing Services: The Results of Two Consecutive Community Surveys Conducted in the Western Cape, South Africa. AIDS Care, 25, 194-201.

[20] Muoghalu, C.O. and Jegede, S.A. (2010) The Role of Cultural Practices and the Family in the Care for People Living with HIV/AIDS among the Igbo of Anambra State, Nigeria. Social Work in Health Care, 49, 981-1006. http://dx.doi.org/10.1080/00981389.2010.518885

[21] Odimegwu, C., Adedeni, S.A. and Ononokpono, D.N. (2013). HIV/AIDS Stigma and Utilization of Voluntary Counselling and Testing in Nigeria. BMC Public Health, 13, 465. http://dx.doi.org/10.1186/1471-2458-13-465

[22] Emeka-Nwabunnia, I., Ibeh, O. and Ogbulie, T. (2014) High HIV Sero-Prevalence among Students of Institutions of Higher Education in Southeast Nigeria. Asian Pacific Journal of Tropical Disease, 4, 159-168. http://dx.doi.org/10.1016/S2222-1808(14)60334-0

[23] Nwachukwu, C.E. and Odimegwu, C. (2011) Regional Patterns and Correlates of HIV Voluntary Counselling and Testing among Youths in Nigeria. African Journal of Reproductive Health, 15, 131-146.

[24] Erinosho, O., Joseph, R., Isiugo-Abanihe, U., Dike, N. and Aderinto, A.A. (2014) Methodological Issues in HIV-Related Social Research in Nigeria. African Journal of Reproductive Health, 17, 146-155.

[25] Li, X., Lin, C., Gao, Z., Stanton, B., Fang, X., Yin, Q. and Wu, Y. (2004) HIV/AIDS Knowledge and the Implications for Health Promotion Programs among Chinese College Students: Geographic, Gender and Age Differences. Health Promotion International, 19, 345-356. http://dx.doi.org/10.1093/heapro/dah308

[26] Maa, W., Detelsb, R., Fengb, Y., Wua, Z., Shenc, L., Lic, Y., Liud, T., et al. (2007) Acceptance of and Barriers to Voluntary HIV Counseling and Testing among Adults in Guizhou Province, China. AIDS, 21, 129-135. http://dx.doi.org/10.1097/01.aids.0000304708.64294.3f

[27] Otasowie, E. (2010) The Knowledge, Attitude and Perception of HIV Voluntary Counseling and Testing (VCT) among Young Adults in Kempton Park Community, North of Ekurhuleni Municipality, Gauteng Province: Improving the Uptake of VCT. Family Medicine and Primary Care, 19, 35-42.

[28] Mbamara, S.U. and Obiechina, N.J. (2013) Awareness and Attitudes toward voluNtary Counseling and Testing for HIV/AIDS among Law Undergraduates in Tertiary Institutions in Southeast Nigeria. Journal of Reproductive Medicine, 58, 55-60.

[29] Ogaji, D.S., Oyeyemi, A.S. and Ibrahim, I. (2014) Awareness, Willingness and Use of Voluntary HIV Testing and Counseling Services by Students of a University in South-South Nigeria. Journal of Community Medicine and Primary Health Care, 25, 36-44.

[30] Osazuwa, F., Dirisu, J.O. and Okuonghae, P.E. (2012) Early Determination of Human Immunodeficiency Virus Status by Routine Voluntary Counseling and Testing in Benin City, Nigeria. North American Journal of Medical Sciences, 4, 99-103. http://dx.doi.org/10.4103/1947-2714.93378

[31] Okusanya, B.O., Ashimi, A.O., Aigere, E.O., Salawu, S.E. and Hassan, R. (2014) Scaling up Prevention of Mother to Child Transmission of HIV Infection to Primary Health Facilities 
in Nigeria: Findings from Two Primary Health Centers in Northwest Nigeria. African Journal of Reproductive Health, 17, 130-137.

[32] United Nations Programme on HIV/AIDS (2012) Federal Republic of Nigeria: Global AIDS Response.

http://www.unaids.org/en/dataanalysis/knowyourresponse/countryprogressreports/2012co untries/Nigeria\%202012\%20GARPR\%20Report\%20Revised.pdf

[33] Leta, T.H., Sandoy, I.F. and Fylkesnes, K. (2012) Factors Affecting Voluntary HIV Counselling and Testing among Men in Ethiopia: A Cross-Sectional Survey. BMC Public Health, 12, 438. http://dx.doi.org/10.1186/1471-2458-12-438

[34] Oladunni, T.M. and Osezua, C. (2013) Acceptance and Uptake of HIV Counseling and Testing by Youth Corp Members in Osun State, Nigeria. International Journal of Asian Social Science, 3, 1381-1388.

[35] Ogunro, P.S., Adeneye, A.K., Akinwusi, P.O. and Ogungbamigbe, T.O. (2013) Willingness to Seek Human Immunodeficiency Virus (HIV) Voluntary Counselling and Testing (VCT) among Urban Residents in Osogbo, South-West Nigeria. Journal of Community Medicine and Primary Health Care, 23, 68-78.

[36] Oyediran, K.A., Feyisetan, O. and Akpan, T. (2011) Predictors of Condom-Use among Young Never-Married Males in Nigeria. Journal Health Population Nutrition, 29, 273-285. http://dx.doi.org/10.3329/jhpn.v29i3.7875

[37] Ojikutu, R.K., Adeleke, I.A., Yusuf, T. and Ajijola, L.A. (2010) Knowledge, Risk Perception and Behaviour on HIV/AIDS among Students of Tertiary Institutions in Lagos State, Nigeria. E-Leader Budapest, 11, 145-153.

[38] Munthali, A.C., Mvula, P.M. and Maluwa-Banda, D. (2014) Knowledge, Attitudes and Practices about HIV Testing and Counselling among Adolescent Girls in Some Selected Secondary Schools in Malawi. African Journal of Reproductive Health, 17, 60-68.

[39] Ikechebelu, I., Udigwe, G., Ikechebelu, N. and Imoh, L. (2006) The Knowledge, Attitude and Practice of Voluntary Counseling and Testing (VCT) for HIV/AIDS among Undergraduates in a Polytechnic in Southeast, Nigeria. Nigerian Journal of Medicine, 15, 245-249.

[40] Haruna, A.S. (2014) Prevalence of Psychological Resistance to Voluntary Counselling and Testing of HIV/AIDS among Students of Tertiary Institutions in Kano State, Nigeria. International Journal of Social, Behavioral, Educational, Economic, Business and Industrial Engineering, 7, 175-179.

[41] Ahmed, S., Delaney, K., Villalba-Diebold, P., Gambo, A., Niel, C. and Man, C. (2013) HIV Counseling and Testing and Access-to-Care Needs of Populations Most-at-Risk for HIV in Nigeria. AIDS Care, 25, 85-94. http://dx.doi.org/10.1080/09540121.2012.686597

[42] Regassa, N. and Kedir, S. (2011) Attitudes and Practices on HIV Preventions among Students of Higher Education Institutions in Ethiopia: The Case of Addis Ababa University. Educational Research, 2, 828-840.

[43] Uzochukwu, B., Uguru, N., Ezeoke, U., Onwujekwe, O. and Sibeudu, T. (2011) Voluntary Counseling and Testing (VCT) for HIV/AIDS: A Study of the Knowledge, Awareness and Willingness to Pay for VCT among Students in Tertiary Institutions in Enugu State Nigeria. Health Policy, 99, 277-284. http://dx.doi.org/10.1016/j.healthpol.2010.11.007

[44] Onyeonoro, U.U., Emelumadu, O.F., Chuku, A., Kanu, O.O., Ebenebe, U.E., Onwukwe, N. and Ndukwe, E. (2014) Knowledge and Utilization of HIV Counseling and Testing Services among Students of a Tertiary Institution in Abia State, South East Nigeria. Journal of HIV and Human Reproduction, 2, 8-14. http://dx.doi.org/10.4103/2321-9157.135743

[45] Federal Ministry of Health (2010) Nigeria Integrated Biological and Behavioral Surveill- 
ance Survey (IBBSS) 2010.

http://www.popcouncil.org/uploads/pdfs/2011HIV IBBSS2010.pdf

[46] United Nations Programme on HIV/AIDS (2012) Federal Republic of Nigeria: Global AIDS Response.

http://www.unaids.org/en/dataanalysis/knowyourresponse/countryprogressreports/2012co untries/Nigeria\%202012\%20GARPR\%20Report\%20Revised.pdf

[47] Manjok, E.S. and Essien, E.J. (2009) HIV/AIDS-Related Stigma and Discrimination in Nigeria: Review of Research Studies and Future Directions for Prevention Strategies. African Journal of Reproductive Health, 13, 21-36.

[48] Federal Ministry of Health (2013) National HIV \& AIDS and Reproductive Health Survey, 2012 (NARHS Plus). Federal Ministry of Health, Abuja.

[49] Makama, G.A. (2013) Patriarchy and Gender Inequality in Nigeria: The Way Forward. European Scientific Journal, 9, 101-110.

[50] Obidoa, C.A., M’Lan, C.E. and Schensul, S.L. (2012) Factors Associated with HIV/AIDS Sexual Risk among Young Women Aged 15-24 Years in Nigeria. Journal of Public Health in Africa, 3, e15. http://dx.doi.org/10.4081/jphia.2012.e15

[51] Walsh, E. (2014) Fostering Leadership to Eliminate Mother-to-Child Transmission of HIV in Nigeria. http://blog.usaid.gov/

[52] United Nations Population Fund (2013) Priority Areas of Support and Key Achievements/ Contributions to Nigeria's HIV/AIDS Response. http://nigeria.unfpa.org/

[53] Egesie, J.O., Joseph, E.D., Egesie, U.G. and Odeh, C.I. (2011) Trends in the Incidence of Hepatitis B, C and Human Immunodeficiency Virus (HIV) among Blood Donors in a Tertiary Hospital in Nigeria. Journal of Medicine in the Tropics, 13, 42-50. http://dx.doi.org/10.4314/jmt.v13i1.69333

[54] Creswell, J.W. (2009) Research Design: Qualitative, Quantitative, and Mixed Methods Approaches. Sage, Thousand Oaks.

[55] DHS/ICF International (2011) Measure DHS. http://www.measuredhs.com

[56] Cozby, P.C. (2009) Methods in Behavioral Research. 10th Edition, McGraw Hill, New York.

[57] Bandura, A. (1977) Self-Efficacy: Toward a Unifying Theory of Behavioral Change. Psychological Review, 84, 191-215. http://dx.doi.org/10.1037/0033-295X.84.2.191

[58] Ibrahim, M., Ipadeola, O., Adebayo, S. and Fatusi, A. (2013) Socio-Demographic Determinants of HIV Counseling and Testing Uptake among Young People in Nigeria. International Journal of Prevention and Treatment, 2, 23-31. 
Submit or recommend next manuscript to SCIRP and we will provide best service for you:

Accepting pre-submission inquiries through Email, Facebook, LinkedIn, Twitter, etc. A wide selection of journals (inclusive of 9 subjects, more than 200 journals)

Providing 24-hour high-quality service

User-friendly online submission system

Fair and swift peer-review system

Efficient typesetting and proofreading procedure

Display of the result of downloads and visits, as well as the number of cited articles

Maximum dissemination of your research work

Submit your manuscript at: http://papersubmission.scirp.org/

Or contactwja@scirp.org 